\title{
Partial purification and characterisation of a synovial fluid inhibitor of osteoblasts
}

\author{
R A Hazelton, R Vedam, P P Masci, A N Whitaker
}

\begin{abstract}
A polypeptide inhibitor of osteoblast proliferation is described which occurs in synovial effusions of patients with rheumatoid arthritis. Partial purification of the inhibitor showed a molecular weight of approximately 81000 by gel electrophoresis. This polypeptide seems to be unique as no inhibitor of osteoblasts of similar molecular weight has been previously described in rheumatoid synovial effusions.
\end{abstract}

Osteoporosis is well recognised in association with rheumatoid arthritis (RA). Generally it is regarded as being of two types, periarticular and generalised osteoporosis. The factors responsible for generalised osteoporosis in RA are multiple and include those resulting in decreased bone formation and enhanced bone loss. Assessment of bone disease in RA is made difficult by the effects, not only of the underlying disease, but also, as the disease progresses, of disuse due to loss of mobility, drug treatment, which may affect bone metabolism, and in some cases poor nutrition. ${ }^{1}$ Juxta-articular loss of bone density may be evident within months after disease onset $^{2}$ and is recognised as a useful diagnostic feature of RA. ${ }^{3}$ This latter form of osteoporosis seems to be mediated by local disease mechanisms. ${ }^{4-6}$

Studies with isolated bone cell populations have found that many well characterised bone resorbing hormones have receptors on osteoblasts and affect osteoblast function. ${ }^{7}$ These hormones include parathyroid hormone, prostaglandin E, 1,25-dihydroxyvitamin $\mathrm{D}_{3}$, and epidermal growth factor. ${ }^{8-10}$ Human tumour necrosis factors $\alpha$ and $\beta$ secreted by monocytelymphocyte preparations have been found in bone organ cultures to stimulate bone resorption and inhibit bone formation. ${ }^{7}$ Fibroblast derived growth factors may also inhibit osteoblast function. ${ }^{11}$ To learn more about the mechanisms of osteoporosis complicating RA the effect of synovial fluid on isolated osteoblasts was studied. A polypeptide which is inhibitory towards osteoblasts has been partially purified and is described below.

\section{Patients and methods}

\section{PATIENTS}

Synovial fluid was obtained from patients with definite or classical RA as determined by the American Rheumatism Association criteria. ${ }^{3}$ Fluids were only obtained during routine diagnostic or therapeutic procedures after informed consent had been given.

\section{MATERIALS}

Sephacryl S-200, Phastgels, and Phastgel buffer strips were obtained from Pharmacia, Uppsala, Sweden. Diethylaminoethyl (DEAE)-52 cellulose was purchased from Whatman Biochemicals, London. Blue-Sepharose was obtained from Bio-Rad, USA. Acrylamide, methylenebisacrylamide, and sodium dodecyl sulphate were obtained from BDH Chemicals, Poole, England. $N, N, N^{\prime}, N^{\prime}$-Tetramethylenediamine and bovine serum albumin were purchased from Sigma Chemical Co, St Louis, Mo, USA. Medium 199 was obtained from Flow Laboratories, Irvine, Scotland and [methyl $-{ }^{3} \mathrm{H}$ ]thymidine from Amersham, Buckinghamshire, UK. Collagenase (type II) was obtained from Worthington, Ohio, USA. All other chemicals were of the highest purity available.

\section{METHODS}

\section{Isolation and culture of bone cells}

Bone cell populations were isolated from the calvaria of 3-4 day old mice (Quackenbush) by a modification of a previously described method. ${ }^{12}$ Briefly, the calvaria, consisting of frontal and parietal bones, were removed aseptically. They were incubated at $37^{\circ} \mathrm{C}$ with $5 \% \mathrm{CO}_{2}$ with gentle stirring in $5 \mathrm{ml}$ of a sterile enzyme solution consisting of $0.4 \%$ collagenase (Worthington type II) and $0 \cdot 1 \%$ bovine serum albumin (Sigma) made up with Medium 199. The initial digestion medium containing freed osteoclast bone cells was decanted and replaced with $5 \mathrm{ml}$ of fresh enzyme solution after 10 minutes' incubation at $37^{\circ} \mathrm{C}$ with $5 \% \mathrm{CO}_{2}$. After the second 90 minute incubation the digestion medium containing freed osteoblast cells was collected. After centrifugation in Medium 199 (270 $\mathrm{g}, 10$ minutes) the osteoblasts were counted in a Coulter counter (Coulter Electronics, Hialeah, Florida). The cells were resuspended in Medium 199 and plated at $1-1.5 \times 10^{5}$ cells/ well in 96 well flat bottom plates $(1.0 \mathrm{~cm} \times 0.6$ $\mathrm{cm}$; Flow Laboratories). In some studies the rat osteosarcoma line UMR-106 was used. ${ }^{12}$ Lineage of calvarial and UMR-106 cells was checked with alkaline phosphatase staining, and on all occasions dense staining for this enzyme was found. ${ }^{13}$

\section{Controls}

With each osteoblast assay appropriate controls were used, including resting cells, human albumin, AB serum, and buffers.

The cells were incubated for 24 hours at $37^{\circ} \mathrm{C}$ with $5 \% \mathrm{CO}_{2}$ before the samples at a $1: 12$ dilution were added. Osteoblast cultures were

Department of Medicine,
Princess Alexandra
Hospital, University of
Queensland, Brisbane,
Queensland, Australia
R A Hazelton
R Vedam
P P Masci
A N Whitaker
Correspondence to:
Dr R A Hazelton,
University Department of
Medicine, Princess Alexandra
Hospital, Ipswich Road,
Woolloongabba, Brisbane
QLD, Australia 4102.
Accepted for publication
15 May 1989


then incubated in quadruplicate with heat treated fetal calf serum together with the test sample. Heat treated fetal calf serum had been previously found to stimulate osteoblasts. After 48 hours of incubation the cultures were pulsed for 18 hours with $37 \mathrm{kBq}$ of [methyl- ${ }^{3} \mathrm{H}$ ] thymidine per well. The cells were harvested with a Skatron multisample harvester, and the incorporation of [methyl- ${ }^{3} \mathrm{H}$ ] thymidine was determined by standard liquid scintillation counting techniques. Data were expressed as the percentage inhibition of heat treated fetal calf serum stimulated osteoblasts.

\section{Ion exchange chromatography}

Pooled synovial fluid was diluted with $50 \mathrm{mM}$ TRIS-HCl buffer (pH 8.0 ) at $4^{\circ} \mathrm{C}$ and was applied to a $2.5 \mathrm{~cm} \times 30 \mathrm{~cm}$ column of DEAE- 52 cellulose. The column was equilibrated with starting buffer-50 mM TRIS-HCl (pH 8.0). A linear gradient of 0 to $500 \mathrm{mM} \mathrm{NaCl}$ (volume= $250 \mathrm{ml}$ ) was applied to the column at a flow of $84 \mathrm{ml} / \mathrm{h}$. An LKB fraction collector (Bromma, Sweden) was used to assay fractions for osteoblast inhibition.

\section{Gel filtration}

The ion exchange fraction eluting between 1211 and $1225 \mathrm{ml}$ (fraction P) was applied to a $2.5 \mathrm{~cm} \times 95 \mathrm{~cm}$ column of Sephacryl S-200 (Pharmacia) which was equilibrated with $50 \mathrm{mM}$ TRIS-HCl buffer ( $\mathrm{pH} 7 \cdot 4$ ) containing $100 \mathrm{mM} \mathrm{NaCl}$. A flow of $45 \mathrm{ml} / \mathrm{h}$ was used and $9.0 \mathrm{ml}$ fractions were collected. Fractions were assayed for osteoblast inhibition.

\section{Polyacrylamide gel electrophoresis}

Sodium dodecyl sulphate-polyacrylamide gel electrophoresis (SDS-PAGE) in a phosphate continuous buffer system ( $\mathrm{pH} 7 \cdot 4$ ) was carried out as described by Weber and Osborn. ${ }^{14}$ Discontinuous PAGE was carried out by the method of Davis. ${ }^{15}$ Pharmacia Phastsystem was used to perform discontinuous PAGE and SDSPAGE. Protein was eluted with TRIS buffer from PAGE gel slices and concentrated with

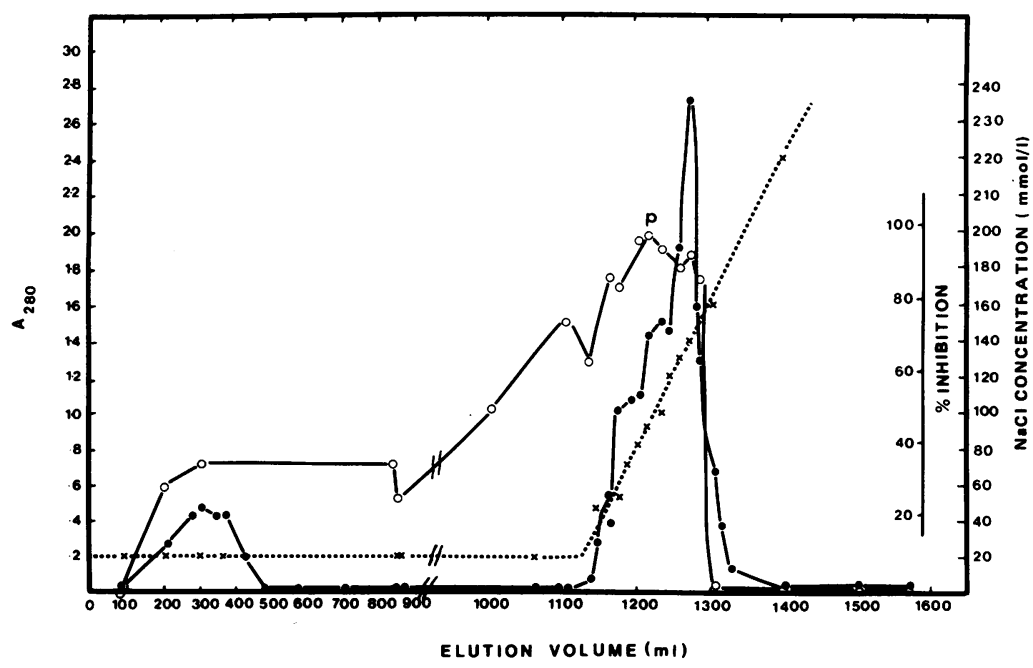

Figure 1: Ion exchange chromatography of pooled synovial fluid $8 \cdot 3 \mathrm{ml}$, diluted 1:20 with $50 \mathrm{mM}$ TRIS-HCl buffer (pH 8.0), DEAE column $(2.5 \mathrm{~cm} \times 30 \mathrm{~cm})$ equilibrated with starting buffer, $50 \mathrm{mM}$ TRIS-HCl buffer $(\mathrm{pH} 8 \cdot 0)$, eluted with a linear gradient of $\mathrm{NaCl}$ concentration $(0.5 \mathrm{~mol} / \mathrm{l}) 250 \mathrm{ml}$. Temperature $4^{\circ} \mathrm{C}$. Fraction volume $14 \mathrm{ml}$. $\mathrm{O}=A_{280}$; $\mathrm{O}=$ percentage inhibition; $\times \ldots . . . \times=$ salt gradient. acetone as described by Hames ${ }^{16}$ before being applied to PAGE or SDS-PAGE. Molecular weights of marker proteins were phosphorylase b 94 000; albumin 66500 ; ovalbumin 43000 ; carbonic anhydrase 30000 ; trypsin inhibito 20000 ; and lactalbumin 14000 . The gels were stained with a silver stain using the method of Merril et $a l .{ }^{17}$

\section{Blue-Sepharose affinity chromatography}

Blue-Sepharose was equilibrated with six changes of starting buffer- $50 \mathrm{mM}$ TRIS-HCl buffer ( $\mathrm{pH} \mathrm{7 \cdot 0)}$ containing $100 \mathrm{mM} \mathrm{KCl}$. After six washes in buffer and centrifuging at $1230 \mathrm{~g}$ for 10 minutes the synovial fluid was diluted $1: 2$ with starting buffer before being applied to an equal volume of Blue-Sepharose to form a slurry. After six washes with starting buffer by centrifuging at $1230 \mathrm{~g}$ for five minutes the bound components were eluted with elution buffer-50 mM TRIS-HCl buffer ( $\mathrm{pH} 7 \cdot 0$ ) with $1500 \mathrm{mM} \mathrm{KCl}$. Aliquots of unbound and bound fractions were dialysed and tested for osteoblast inhibition.

\section{Results}

CONTROLS

There was no significant inhibition of tritiated thymidine incorporation (this ranged from 0 to $15 \%$ in the many assays performed) or evidence of morphological change by light microscopy with any of the controls used in the osteoblast assay.

ION EXCHANGE CHROMATOGRAPHY

Maximal osteoblast inhibition occurred in fraction $P$ which eluted between 1211 and 1225 $\mathrm{ml}$ (fig 1).

\section{GEL FILTRATION}

Fraction D eluting between 245 and $259 \mathrm{~m}$ showed the greatest osteoblast inhibition (fig 2).

\section{GEL ELECTROPHORESIS}

Ion exchange and Sephacryl S-200 fractions $P$ and $\mathrm{D}$ respectively were subjected to SDSPAGE in the presence of 2-mercaptoethanol, and the gels were stained with silver nitrate. The ion exchange fraction $P$ contained nine major bands and several minor bands. The bands were of various molecular weights. Some were high molecular weight, several bands were similar in molecular weight to albumin (66 500), and three bands were in the low molecular weight region with molecular weights of 30000 , 20000 , and 14000 (fig 3a, column P). Sephacryl S-200 fraction D contained five bands. These included two fine bands, which appeared to comigrate with human serum albumin and prealbumin, and a third band with a molecular weight of 81000 , which was also one of the bands observed in fraction $P$ (fig 3a, column $D$ ).

Unfractionated synovial fluid, ion exchange fraction P, and Sephacryl S-200 fraction D were subjected to PAGE. Synovial fluid and the ion exchange fraction were found to contain several 


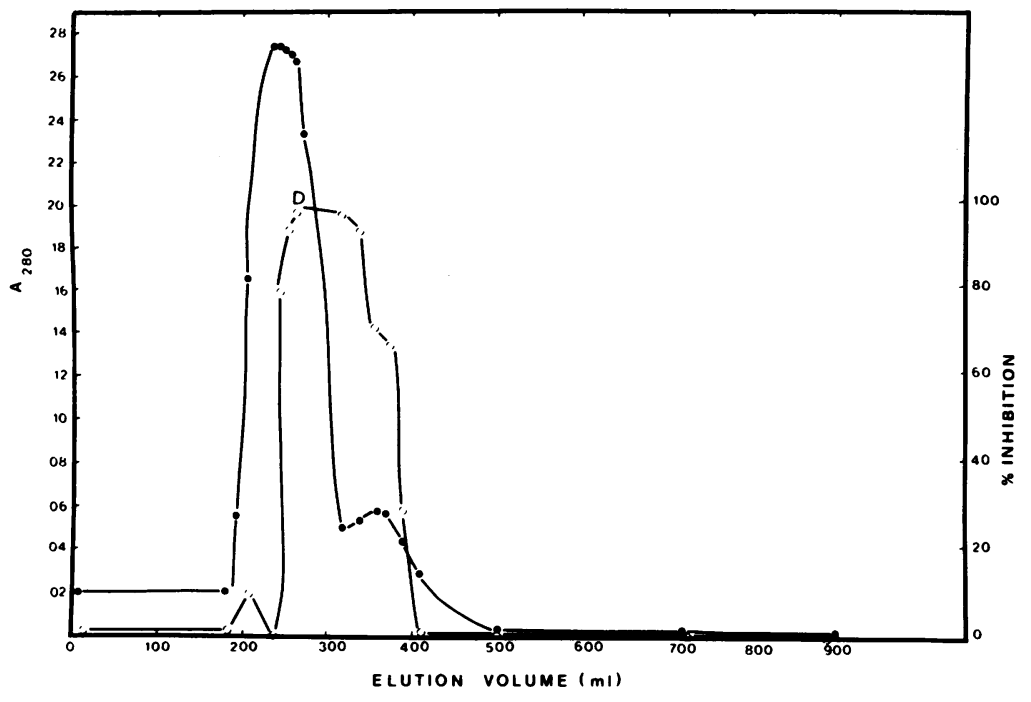

Figure 2: Sephacryl S-200 chromatography of pooled ion exchange fraction $P$.

Column $(2.5 \mathrm{~cm} \times 95 \mathrm{~cm})$ equilibrated with $50 \mathrm{mM}$ TRIS-HClbuffer ( $p H 7 \cdot 4$ ), containing $100 \mathrm{mM} \mathrm{NaCl}$. Temperature $4^{\circ} \mathrm{C}$. Fraction volume $14 \mathrm{ml} . \mathrm{O}=A_{2 \times 0}$; $\mathrm{O}=$ percentage inhibition.

Figure 3: (a) Sodium dodecyl sulphatepolyacrylamide gel electrophoresis

$(S D S-P A G E)$ in the presence of

2-mercaptoethanol of $D=$ the Sephacryl $S-200$ fraction $D$ indicates the 81000 molecular weight band); $P=$ ion exchange fraction $P ; M=$ marker proteins of known molecular weight. (b) Discontinuous $P A G E$ of $D=$ Sephacryl $S$-200 fraction $D$ ( indicates the single band); $P=$ ion exchange fraction $P$, $S F=$ synovial fluid . The gels were stained with silver nitrate. bands (fig 3b, columns SF and P respectively). with silver staining (fig $3 b$, column D).

\section{BLUE-SEPHAROSE AFFINITY CHROMATOGRAPHY}

Synovial fluid was subjected to Blue-Sepharose affinity chromatography and wash and elution fractions were assayed for osteoblast inhibition. Maximum inhibition was observed in the wash fractions and no inhibition was observed in the eluted fractions. The washed fraction was then subjected to PAGE and the different bands cut out. Protein was eluted from the gel slices by diffusion and assayed for osteoblast inhibition. Most inhibition occurred in one gel slice. When this gel slice was subjected to SDS-PAGE in the presence of 2-mercaptoethanol three visible bands were seen with the middle band migrating the same distance as albumin (fig 4a, column A). With PAGE one band was found with silver staining (fig $4 \mathrm{~b}$, column $\mathrm{B}$ ).

The table shows the results of the two purification sequences and indicates similar improvements in specific activity over the starting synovial fluid samples.

Light microscopic assessment showed that at least $80 \%$ of cells rounded up and developed an intracellular granular appearance and would no longer take up tritiated thymidine after culture with the inhibitor. These appearances were observed with both calvarial osteoblasts and UMR-106 cells. An S-200 enriched preparation of the inhibitor did not cause calvarial cell death as judged by trypan blue dye exclusion.

\section{Discussion}

This is the first report of an inhibitor of

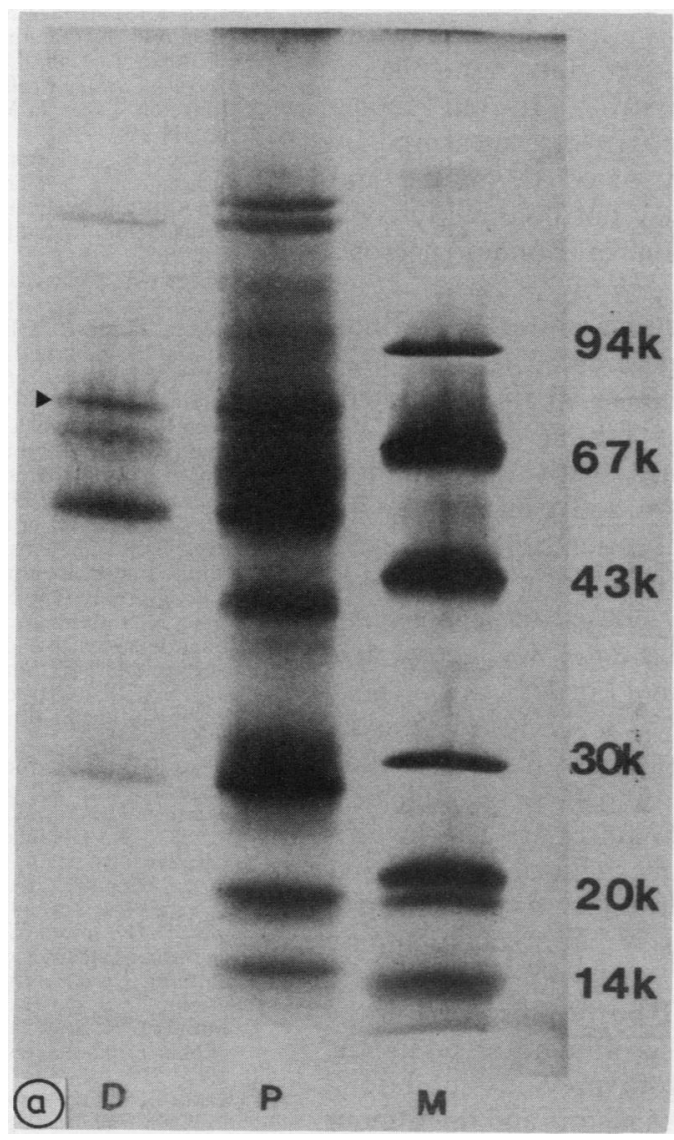

Purification table

\begin{tabular}{|c|c|c|c|}
\hline Material & $\begin{array}{l}\text { Protein } \\
(\mathrm{g} / \mathrm{l})\end{array}$ & $\begin{array}{l}\% \\
\text { Inhibition }\end{array}$ & $\begin{array}{l}\text { Specific } \\
\text { activity }\end{array}$ \\
\hline $\begin{array}{l}\text { Pooled synovial fluid } \\
\text { DEAE*-52 fraction P } \\
\text { Sephacryl S-200 fraction D }\end{array}$ & $\begin{array}{l}110 \\
1.17 \\
0.052\end{array}$ & $\begin{array}{l}8 \\
95 \\
98\end{array}$ & $\begin{array}{r}4060 \\
98000\end{array}$ \\
\hline $\begin{array}{l}\text { Starting synovial fluid } \\
\text { Blue-Sepharose washed }\end{array}$ & 17.9 & 44 & 123 \\
\hline $\begin{array}{l}\text { fraction } \\
\text { PAGE }^{*} \text { gel slice }\end{array}$ & $\begin{array}{l}1 \cdot 2 \\
0.05\end{array}$ & $\begin{array}{l}49 \\
69\end{array}$ & $\begin{array}{r}2042 \\
99000\end{array}$ \\
\hline
\end{tabular}

${ }^{*}$ DEAE = diethylaminoethyl; PAGE = polyacrylamide gel electrophoresis.

The starting synovial fluid was selected after prior assaying to ensure significant inhibition. In the first purification sequence pooled synovial fluid $(n=3)$ was used, whereas in the second sequence fluid from a single patient was used. Albumin showed some inhibition of tritiated thymidine incorporation by osteotimes more active. blasts, but on a weight for weight basis the inhibitor was over 720 


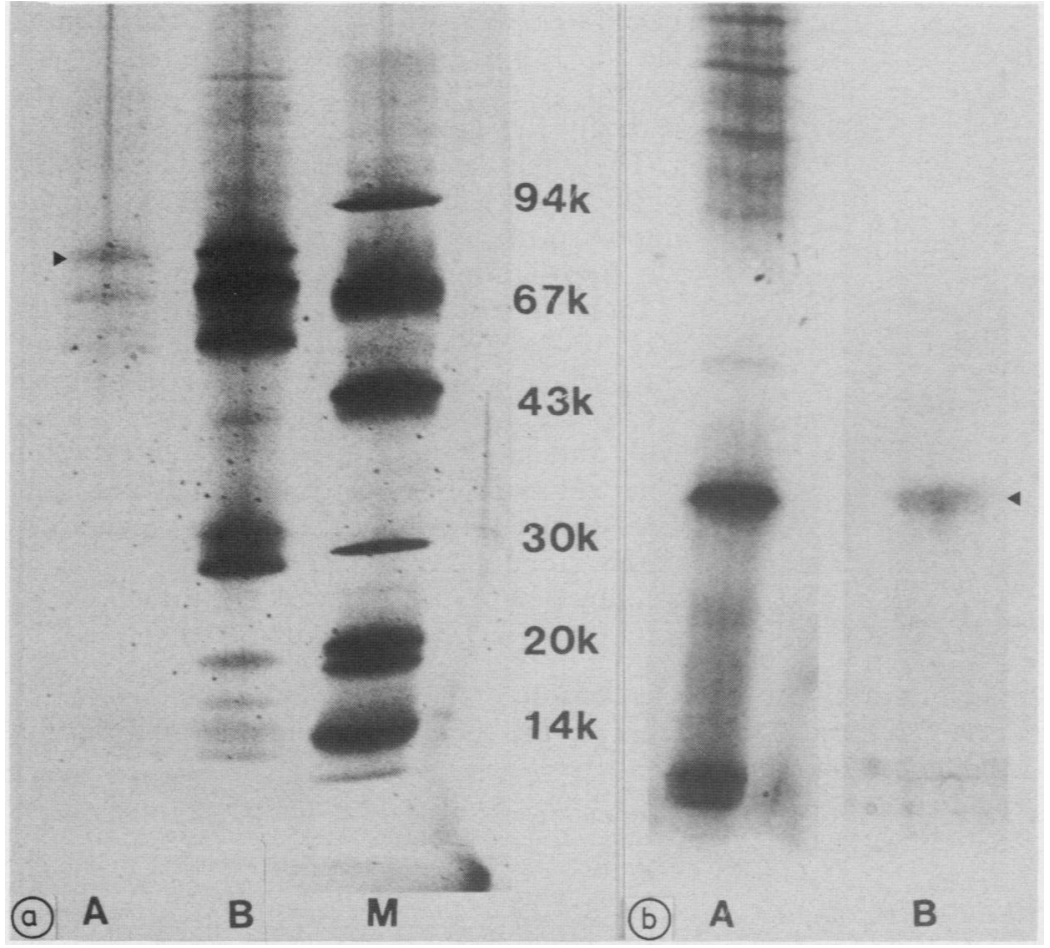

Figure 4: (a) Sodium dodecyl sulphatepolyacrylamide gel electrophoresis $(S D S-P A G E)$ in the presence of

2-mercaptoethanol of $A=P A G E$ gel slice ( indicates the 81000 molecular weight band), $B=B l u e-S e p h a r o s e$ washed fraction; $M=$ marker proteins of known molecula weight. (b) Discontinuous $P A G E$ of $A=$ BlueSepharose washed fraction; $B=$ gel slice with maximal osteoblast inhibition ( indicates the single band). The gels were stained with silver nitrate. osteoblasts described in rheumatoid synovial fluid. The inhibitor significantly decreased tritiated thymidine incorporation of both murine osteoblast and rat osteosarcoma cells and microscopically resulted in morphological changes during culture. The inhibitor is probably a polypeptide of molecular weight 81000 , which under reducing and denaturing conditions consists of two separate bands on gel electrophoresis (figs $3 a$ and $b$ ). Known inhibitors of osteoblast function, including tumour necrosis factors $\alpha$ and $\beta$ (previously called cachectin and lymphotoxin respectively), have been shown to inhibit rat bone collagen and non-collagen protein synthesis in vitro. ${ }^{18}$ In our report osteoblast inhibitory activity was measured by the incorporation of tritiated thymidine and therefore our results may not be directly comparable with the action of tumour necrosis factor on osteoblasts.

The separation of the inhibitor with BlueSepharose was undertaken because of the high concentration of albumin in all fluids studied. Albumin was found to inhibit osteoblasts at high concentration only, with the inhibitor being over 720 times more active on a weight for weight basis. Both purification procedures gave similar improvements in specific activity over starting samples (table). Based on a molecular weight of 81000 the inhibitor was active at a concentration of $3.3 \mu \mathrm{mol} / \mathrm{l}$ or less.

Studies showed that $57 \%(17 / 30)$ of synovial fluid samples from patients with RA inhibited osteoblast proliferation. At present the biological role of this inhibitor requires further investigation. The possible mechanism of action is uncertain, though according to trypan blue dye exclusion the inhibitor is not toxic to mouse calvarial cells.

This inhibitor could be responsible for the periarticular osteoporosis often observed in RA. It appears different from previous inhibitors, such as fibroblast growth factors and the tumour necrosis factors $\alpha$ and $\beta$. Although fibroblast growth factors increase the number of osteoblastic cells, they may under some conditions directly inhibit osteoblastic function. ${ }^{11}$ Tumour necrosis factors $\alpha$ and $\beta$ show time dependent dual stimulatory and inhibitory effects on bone formation. ${ }^{1920}$ The molecular weights of these inhibitors are much less than that of the inhibitor found in RA synovial fluid, suggesting that the latter is unique.

The above is a preliminary report of the partial purification of a polypeptide inhibitor of osteoblast proliferation found in rheumatoid synovial effusions. Further work is aimed at defining the structure and function of this inhibitor.

Supported by grants from the Arthritis Foundation of Australia the Rebecca L Cooper Foundation, and the Mayne bequest fund of the University of Queensland. The UMR-106 cells were kindly donated by Professor T J Martin of Melbourne, Victoria, Australia.

1 Wordsworth B P, Vipond S, Woods C G, Mowat A G Metabolic bone disease among in-patients with rheumatoid arthritis. Br $\mathcal{F}$ Rheumatol 1984; 23: 251-7.

2 Bywaters E G L. The early radiological signs of rheumatoid arthritis. Bull Rheum Dis 1960; 11: 231-4.

3 Ropes M W, Bennett G A, Cobb S, et al. Proposed diagnostic criteria for rheumatoid arthritis. Ann Rheum Dis 1959; 18: $49-53$.

4 Robinson D R, Tashjian A M, Levine L. Prostaglandin stimulated bone resorption by rheumatoid synovia. F Clin Invest 1975; 56: 1181-8.

5 Mizel S B, Dayer J M, Krane S M, Mergenhagen S E. Stimulation of rheumatoid synovial cell collagenase and prostaglandin production by purified lymphocyte-activating factor (interleukin 1). Proc Natl Acad Sci USA 1981; 78: 2475-7.

6 Crisp A J, Roelke M S, Goldring S R, Krane S M. Heparin modulates intracellular cyclic AMP in human trabecular bone cells and adherent rheumatoid synovial cells. Ann Rheum Dis 1984; 43: 628-34.

7 Martin T J. Drug and hormone effects on calcium release from bone. Pharmacol Ther 1983; 21: 209-28.

8 Partridge N C, Frampton R J, Eisman J A, Michelangell V P Elms E, Bradley T R. Receptors for $1,25(\mathrm{OH})_{2}$-vitamin D 3 in cloned osteoblast-like rat osteogenic sarcoma cells. FEBS Lett 1980; 115: 139-43.

9 Martin T J, Partridge N C. Initial events in the activation of bone cells by parathyroid hormone, prostaglandins and calcitonin. In: Cohn D V, Talmage R V, Matthews J L, eds. Hormonal control of calcium metabolism. Amsterdam, Oxford Princeton: Excerpta Medica, 1981: 147-59. (Int Congr Ser No 511 .)

10 Partridge N C, Kemp B E, Veroni M C, Martin T J Activation of $3^{\prime}, 5^{\prime}$-monophosphate-dependent protein kinase in normal and malignant bone cells by parathyroid hormone, prostaglandin $\mathrm{E}_{2}$ and prostacyclin. Endocrinology 1981;108: $220-5$.

11 McCarthy T, Centrella M, Fox G, Arakawa T, Canalis E. Endothelial cell growth factor (ECGF) and basic fibroblast growth factor (bFGF) independently regulate bone cell replication and type 1 collagen transcription and translation [Abstract]. Fournal of Bone and Mineral Research 1987; 2 [Abstract]. Fou

12 Luben R A, Wong G L, Cohn D V. Biochemical characterization with parathormone and calcitonin of isolated bone cells. provisional identification of osteoclasts and osteoblasts. Endocrinology 1976; 99: 526-34.

13 Partridge N C, Alcorn D, Michelangeli V P, Kemp B E Ryan G B. Functional properties of hormonally responsive cultured normal and malignant rat osteoblastic cells. Endocrinology 1981; 108: 213-9.

14 Weber $K$, Osborn $M$. The reliability of molecular weight determinations by dodecyl sulphate-polyacrylamide gel electrophoresis. F Biol Chem 1969; 244: 4406-12.

15 Davis B J. Disc electrophoresis. II. Method and application to human serum proteins. Ann NY Acad Sci 1964; 121: 404-27.

16 Hames B D. An introduction to polyacrylamide gel electrophoresis. In: Gel electrophoresis of proteins: a practical

17 Merril C R, Goldman D, Sedman S A, Ebert M H Ultrasensitive stain for proteins in polyacrylamide gels shows regional variation in cerebrospinal fluid proteins Science 1981; 211: 1437-8.

18 Smith D D, Gowen M, Mundy G R. Effects of interferon- $\gamma$ and other cytokines on collagen synthesis in fetal rat bone cultures. Endocrinology 1987; 120: 2494-9.

19 Bertolini D R, Nedwin G E, Bringman G S, Smith D D Mundy G R. Stimulation of bone resorption and inhibition of bone formation in vitro by human necrosis factors. Nature 1986; 319: $516-8$.

20 Canalis E. Effects of tumor necrosis factor on bone formation in vitro. Endocrinology 1987; 121: 1596-604. 